\title{
Maritime Lighthouses in the Republic of Croatia - Safety of Navigation and/or Tourist Attraction
}

\section{Tatjana Stanivuk ${ }^{a}$, Ivan Juričevićb, Jelena Žanić Mikuličića}

The lighthouses are the most important navigation aids enabling safe navigation. Today, in the Republic of Croatia there are 46 maritime lighthouses in function. All the lighthouses are automated and controlled through the remote control system. In the Republic of Croatia, Plovput company is responsible for their maintenance. In recent years maritime lighthouses have increasingly been used for tourism. Still, their primary role has not been forgotten. The proof of this is the incorporation of the Automatic Identification System (AIS) in the lighthouses, raising the safety of navigation to a higher level. Interesting has been the market research in recent years, since there has been an increasing demand for lighthouses as tourist facilities. This is of great importance, as it provides additional financial resources for their maintenance. Unfortunately, the statistical data on renting and the availability of accommodation capacities indicates that there is space for improvement.

\section{KEY WORDS}

$\sim$ Maritime lighthouses

$\sim$ Safety of navigation

$\sim$ Statistical analysis

$\sim$ Tourist attraction a. University of Split, Faculty of Maritime Studies, Split, Croatia

e-mail: tstanivu@pfst.hr

b. PLOVPUT d.o.o., Split, Croatia

e-mail: ivan.juricevic@plovput.hr

doi: 10.7225/toms.v07.n01.003

This work is licensed under (cc) BY

\section{INTRODUCTION}

Man has always sought to mark maritime routes to make navigators safer. For this purpose, various marine signalling facilities were built. In the beginning, fire was lit (Pearson, 1995) and later, with the development of technology, lighthouses and other navigational aids such as coastal and harbour lights, signalling stations, light and signalling signs, signal buoys and other signs started to be established (Jeremić, 2014).

The lighthouses are the most important and safest sea navigation aids that enable safe day and night navigation in a particular marine area. They are built at the most prominent and/ or the most distant points of the Croatian territorial sea. Today, in the Republic of Croatia there are 46 maritime lighthouses, of which 17 have lighthouse station and 29 are without human crew (Pomorski rječnik, 2017; Plovput, 2017).

All the lighthouses are automated and monitored through the remote monitoring system that provides permanent insight into the state of the equipment and devices on the most important 103 maritime signalling objects in order to ensure emergency intervention and to return the light to its function in navigation.

The lighthouses are mostly equipped with main and auxiliary lights. The main range is up to 30 miles. Some lighthouses are equipped with a radar beacon (racon), and /or fog system (fog detector and fog sirens) (Pomorski rječnik, 2017; Plovput, 2017).

In recent years, maritime lighthouses have increasingly been used for tourism, especially in the Republic of Croatia. However, the results of the collected and processed data shown in the Chapter 3 of this paper increasingly point to the importance of incorporating maritime lighthouses into the tourist offer. 


\section{MARITIME LIGHTHOUSES IN THE REPUBLIC OF CROATIA}

In the alphabetic order, all maritime lighthouses in the Republic of Croatia are: Babac, Blitvenica, Crna punta, Glavat, Grebeni, Grujica, Host, Jadrija, Marlera, Mlaka, Mulo, Murvica, Oštri rat, Oštro Kraljevica, Palagruža, Peneda, Pločica, Pokonji dol, Pomorac, Porer, Prestenice, Prišnjak, Ražanj, Savudrija, Sestrica vela - Korčula, Sestrica vela -Tajer, Split breakwater, Stončica, Stražica, Struga, Sućuraj, Sušac, Susak, St. Andrija, St. Ivan at sea, St. Nikola, St. Petar, Tri Sestrice- Rivanj, Trstenik, Veli rat, Verudica, Vir, Vnetak, Vošćica, Zaglav, Zub (Plovput, 2017).

In accordance with the Maritime Law of the Republic of Croatia the primary role of the lighthouse is the safety of navigation and protection of human life. Its secondary role is to ensure the provision of services of public interest, among which are:

- Renovation and maintenance of waterways,

- Establishment and maintenance of navigation aids,

- Radio service of coastal radio stations.

These activities are performed by the company Plovput, while the administrative control is carried out by the Croatian Ministry of the Sea, Traffic and Infrastructure. Objects of maritime safety are facilities and/or technical systems that acoustically and visually, or through electromagnetic waves transmit, receive or exchange information of importance for the safety of persons and maritime objects (Kasum et al., 2013), protection of the marine environment or safety of people, maritime objects and ports that are located on the waterfront. Navigation safety facilities are installed in the inland waters and the territorial sea of the Republic of Croatia in order to ensure the safe conduct of maritime traffic.

It is important to emphasize that over the past 10 years, there have been no maritime accidents which resulted in casualties, and which were caused by unlit signalling lights. In the Republic of Croatia, there are at present 1,065 marine signalling facilities maintained by Plovput, of which 704 maritime signalling objects are owned by Plovput, i.e. the Republic of Croatia, according to the Maritime Code (OG 181/04, 76/07, 146/08, $61 / 11$, 56/13 and 26/15) (Zakon o Plovputu, 1997).

\subsection{Investments in Lighthouses for Safety and Tourism}

By the automation of lights on the lighthouses, which Plovput carried out in the late 1990s, and according to the decision of the Managing Board, lighthouse human crews were withdrawn. The idea that then emerged was to hand over the abandoned lighthouses to wealthy foreigners. The project was called "Pharos", rated socially and economically unacceptable and was rejected. It is important to point out that reducing the number of lighthouse crew did not have any impact on the quality of the basic activities of Plovput, which is the safety of navigation.

In 2011, the realization of the "Stone Lights" project began, which was accepted by the public and the relevant Ministry (Šerić, 2017). The aforementioned project aimed at financial

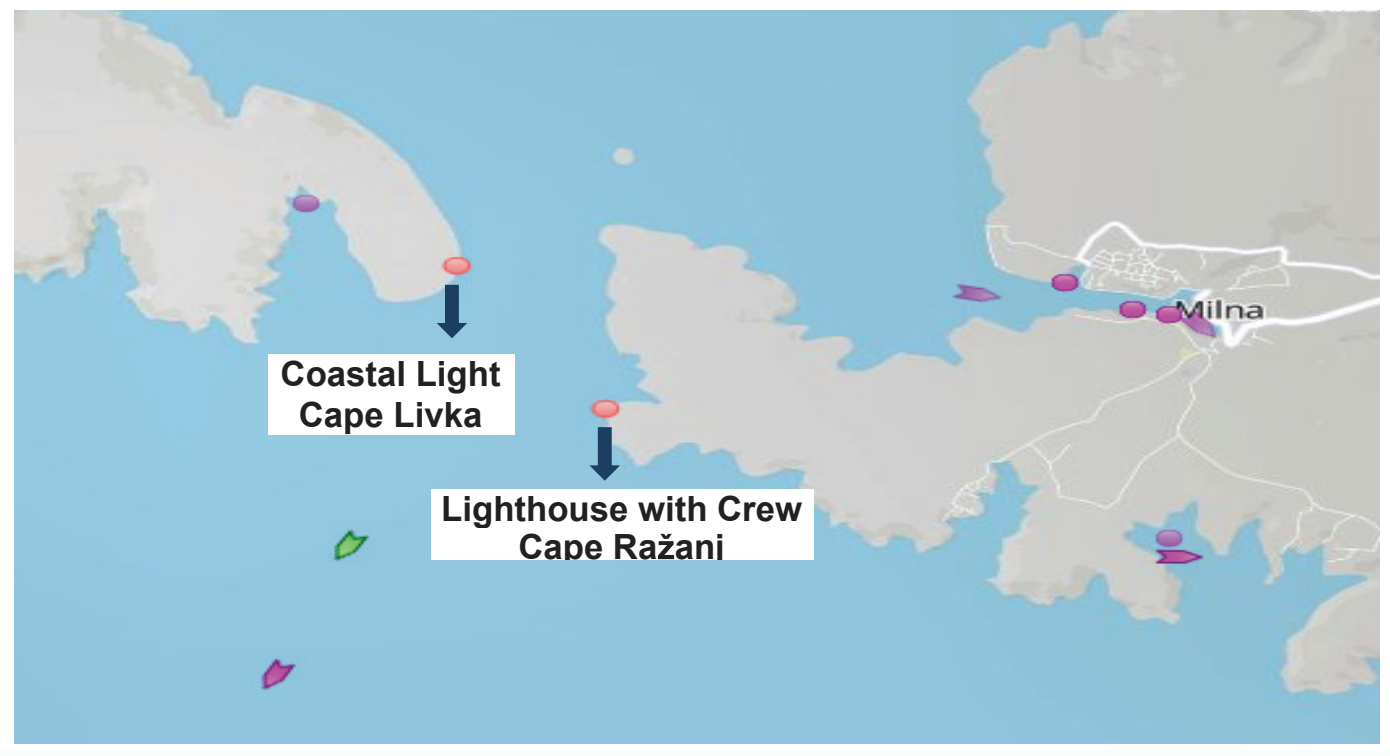

Figure 1.

Split Gates. 
investing in lighthouse buildings to represent a specific tourist service as such. In practice, this idea has proven to be profitable.

The absolute priority of Plovput is an investment in the basic activity, which implies that lighthouses are primarily used as navigation aids, and then inclusion in the tourist offer, which provides additional funding for the maintenance of those facilities (Perišić et al., 2010). During the previous years, Plovput allocated significant financial resources for renovation of the lighthouses. So, in 2008 through its programme of work it planned to spend approximately 4,000,000.00 HRK for the construction of lighthouse buildings, investments, and regular maintenance.

It is important to emphasise that the basic purpose of a lighthouse is to indicate to ships navigable waterways. In the past 2 or 3 years, Plovput invested in the safety of navigation by incorporating AIS (Automatic Identification System) receivers into the most important lighthouses (Categories 1), thus enabling the ship to identify it better through electronic devices.

In this way, the safety of navigation has been raised to a high level for several reasons. Besides the fact that the seafarers can control the position of the ship when seeing the reflection of light from a lighthouse, they also have the orientation in which direction they could ply. As it is well-known, there can always be unexpected failures in lighthouses (bulb, solar regulator, storm strike, etc.), and for these reasons Plovput has introduced AIS devices to duplicate the transmission signal to the ship. In this way, offshore accidents are reduced to a minimum.

\section{LIGHTHOUSES IN THE CROATIAN TOURIST OFFER - CONCESSIONAIRES}

There are 46 lighthouse objects in the Croatian part of the Adriatic. These objects hold a total of $10,398 \mathrm{~m}^{2}$ of enclosed space, of which $83 \%$ falls on residential buildings, while the other facilities are auxiliary ones. Thirteen lighthouse objects, almost a quarter, are in rent (see Table 1). For nine lighthouses, a long-term rent was agreed for 10 years, while the remaining four of them have a renting contract of 5 years.

There are numerous advantages of renting a lighthouse where there is a lighthouse keeper (Šerić, 2001) compared to those where there is none. Namely, lighthouses are of inestimable value and as such are protected as cultural monuments in the Republic of Croatia (Izvod iz registra kulturnih dobara, 2011).

The lighthouse keeper has his assignments including transmitting meteorological reports (Popović et al., 2014) via VHF (Coastal Radio Stations), main and auxiliary light control, seeing nearby lights, observation of the sea state (Pomorski rječnik, 2017). Taking into account all these technical duties of a lighthouse keeper, one can only imagine what malfunctions happen on the unmanned lighthouses. The light is automated and monitored by remote control, so navigation safety is not questionable, but all the other segments are missing. The advantage is to have a lighthouse keeper on the lighthouse, especially if this lighthouse also provides rental facilities (apartments). The lighthouse as such provides additional service, which contributes to considerable financial resources and facilitates the owner's maintenance.

Table 1.

Lighthouse objects in rent.

\begin{tabular}{llll} 
Ord. No & Maritime Lighthouse & Place & Year of rent \\
\hline 1. & Tri sestrice Rivanj & Zadar & 2010 \\
\hline 2. & Marlera & Pula & 2010 \\
\hline 3. & Pokonji dol & Hvar & 2011 \\
\hline 4. & Verudica & Pula & 2011 \\
\hline 5. & Cape Zub & Poreč & 2011 \\
\hline 6. & Vir & Zadar & 2012 \\
\hline 7. & Sućuraj & Sućuraj - Hvar & 2012 \\
\hline 8. & Host & Vis & 2012 \\
\hline 9. & Sestrica vela & Korčula & 2013 \\
\hline 10. & Grebeni & Dubrovnik & 2014 \\
\hline 11. & Crna Punta & Rijeka & 2014 \\
\hline 12. & Vošćica & Krk & 2015 \\
\hline 13. & Olipa & Dubrovnik & 2015 \\
\hline
\end{tabular}


Table 2.

Lighthouses in the Croatian tourist offer.

\begin{tabular}{|c|c|c|c|c|c|}
\hline Ord. No. & Maritime Lighthouse & Place & Renting period & Apartments & Beds \\
\hline 1. & Savudrija & Pula & The whole year & 5 & 20 \\
\hline 2. & St Ivan at sea & Pula & Seasonal & 2 & 8 \\
\hline 3. & Porer & Pula & Seasonal & 2 & 8 \\
\hline 4. & Veli Rat & Zadar & The whole year & 2 & 7 \\
\hline 5. & Prišnjak & & Seasonal & 1 & 5 \\
\hline 6. & Tajer & & Seasonal & 2 & 8 \\
\hline 7. & St Petar & Makarska & Seasonal & 1 & 4 \\
\hline 8. & Sušac & Sušac & Seasonal & 2 & 8 \\
\hline 9. & Palagruža & Palagruža & Seasonal & 2 & 8 \\
\hline 10. & Struga & & The whole year & 4 & 15 \\
\hline 11. & Pločica & Korčula & seasonal & 2 & 16 \\
\hline 12. & St Andrija & Dubrovnik & seasonal & 1 & 6 \\
\hline
\end{tabular}

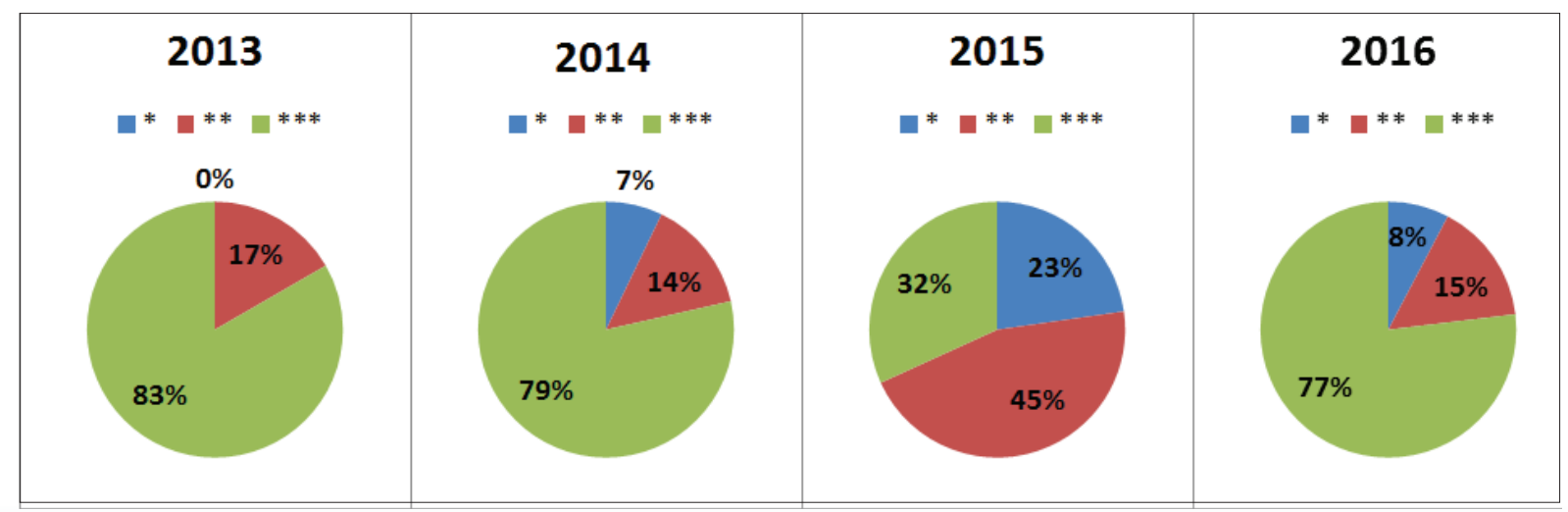

Figure 2.

Structure of the lighthouses according to the categories.

Categorization of lighthouses is similar to that of the apartments; blue colour indicates the lowest (1 star), red middle ( 2 stars), and green the highest categorization (3 stars).

From the aspect (see Figure 2) on the maritime lighthouse structure by categorization, it is apparent that since 2013 the categorization has not been improved, although significant funds have been invested in the previous periods. It can be concluded that the situation in which the lighthouses are currently managed does not allow it, although it is indispensable.

\subsection{Availability of Accommodation Capacities - Results and Discussion}

Of the total number of guests on the lighthouses, domestic tourists occupy $15 \%$; the rest falls on foreign tourists, mostly from Italy, then guests of the German-speaking area such as Austria, Germany, Switzerland, and tourists from Eastern Europe. Tables $3,4,5$ and 6 indicate oscillations in renting, and by comparing those Tables it is not easy to conclude why the oscillations occur. Unfortunately, they are also good indicators of low availability and underutilization as well as the need to raise lighthouse categorisation and their promotion. 
Table 3.

Results of tourist rent in 2013.

\begin{tabular}{lllll} 
Ord. No. & Maritime Lighthouse & Place & No. of apartments /beds & Availability in a week period \\
\hline 1. & ML Savudrija & PP Pula & $1 / 4$ & 22 \\
\hline 2. & ML St Ivan at sea & PP Pula & $2 / 8$ & 33 \\
\hline 3. & ML Porer & PP Pula & $2 / 8$ & 17 \\
\hline 4. & ML Veli rat & PP Zadar & $2 / 7$ & 35 \\
\hline 5. & ML Prišnjak & PP Šibenik & $1 / 4$ & 20 \\
\hline 6. & ML St Petar & PP Split & $1 / 4$ & 18 \\
\hline 7. & ML Sušac & PP Korčula & $2 / 8$ & 8 \\
\hline 8. & ML Palagruža & PP Korčula & $2 / 8$ & 16 \\
\hline 9. & ML Struga & PP Korčula & $4 / 14$ & 29 \\
\hline 10. & ML Pločica & PP Korčula & $2 / 14$ & 9 \\
\hline 11. & ML St Andrija & PP Dubrovnik & $1 / 6$ & 26 \\
\hline 12. & ML Grebeni & PP Dubrovnik & $1 / 8$ & 3 \\
\hline
\end{tabular}

\section{Table 4.}

Results of tourist rent in 2014.

\begin{tabular}{lllll} 
Ord. No. & Maritime Lighthouse & Place & No. of apartments /beds & Availability in a week period \\
\hline 1. & ML Savudrija & PP Pula & $1 / 4$ & 24 \\
\hline 2. & ML St Ivan at sea & PP Pula & $2 / 8$ & 14 \\
\hline 3. & ML Porer & PP Pula & $2 / 8$ & 14 \\
\hline 4. & ML Veli rat & PP Zadar & $2 / 7$ & 19 \\
\hline 5. & ML Prišnjak & PP Šibenik & $1 / 4$ & 14 \\
\hline 6. & ML St Petar & PP Split & $1 / 4$ & 16 \\
\hline 7. & ML Sušac & PP Korčula & $2 / 8$ & 18 \\
\hline 8. & ML Palagruža & PP Korčula & $2 / 8$ & 11 \\
\hline 9. & ML Struga & PP Korčula & $4 / 14$ & 16 \\
\hline 10. & ML Pločica & PP Korčula & $2 / 14$ & 13 \\
\hline 11. & ML St Andrija & PP Dubrovnik & $1 / 6$ & 5 \\
\hline 12. & $M L$ Tajer & & $2 / 8$ & 1 \\
\hline & & TOTAL & 165 \\
\hline
\end{tabular}


Table 5.

Results of tourist rent in 2015.

\begin{tabular}{|c|c|c|c|c|}
\hline Ord. No. & Maritime Lighthouse & Place & No. of Apartments/beds & Availability in a week period \\
\hline 1. & ML Savudrija & PP Pula & $1 / 4$ & 40 \\
\hline 2. & ML St Ivan at sea & PP Pula & $2 / 8$ & 21 \\
\hline 3. & ML Porer & PP Pula & $2 / 8$ & 27 \\
\hline 4. & ML Veli rat & PP Zadar & $2 / 7$ & 35 \\
\hline 5. & ML Prišnjak & PP Šibenik & $1 / 4$ & 18 \\
\hline 6. & ML St Petar & PP Split & $1 / 4$ & 14 \\
\hline 7. & ML Sušac & PP Korčula & $2 / 8$ & 8 \\
\hline 8. & ML Palagruža & PP Korčula & $2 / 8$ & 30 \\
\hline 9. & ML Struga & PP Korčula & $4 / 14$ & 21 \\
\hline 10. & ML Pločica & PP Korčula & $2 / 14$ & 21 \\
\hline 11. & ML St Andrija & PP Dubrovnik & $1 / 6$ & 6 \\
\hline \multirow[t]{2}{*}{12.} & ML Tajer & & $2 / 8$ & 6 \\
\hline & & & TOTAL & 259 \\
\hline
\end{tabular}

Table 6.

Results of tourist rent in 2016.

\begin{tabular}{lllll} 
Ord.No. & Maritime Lighthouse & Place & No of apartments/beds & Availability in a week period \\
\hline 1. & ML Savudrija & PP Pula & $1 / 4$ & 42 \\
\hline 2. & ML St Ivan at sea & PP Pula & $2 / 8$ & 21 \\
\hline 3. & ML Porer & PP Pula & $2 / 8$ & 27 \\
\hline 4. & ML Veli rat & PP Zadar & $2 / 7$ & 37 \\
\hline 5. & ML Prišnjak & PP Šibenik & $1 / 4$ & 18 \\
\hline 6. & ML St Petar & PP Split & $1 / 4$ & 14 \\
\hline 7. & ML Sušac & PP Korčula & $2 / 8$ & 8 \\
\hline 8. & ML Palagruža & PP Korčula & $2 / 8$ & 30 \\
\hline 9. & ML Struga & PP Korčula & $4 / 14$ & 22 \\
\hline 10. & ML Pločica & PP Korčula & $2 / 14$ & 21 \\
\hline 11. & ML St Andrija & PP Dubrovnik & $1 / 6$ & 6 \\
\hline 12. & ML Tajer & & $2 / 8$ & 6 \\
\hline & & TOTAL & 252 \\
\hline
\end{tabular}

From Figure 3 it is evident that the lighthouse ML Grebeni was rented only in 2013. After that, it is given in concession, and in 2014 Plovput categorises the lighthouse PS Tajer, which quickly becomes a recognisable tourist attraction.

The average price of the apartment depends on the rental period during the year (before and after the season or the main season). From the above tables (see Table $3,4,5,6$ ) it is apparent that there are 228 weekly rentals on average per year, which is 19 weeks or $8.3 \%$ per lighthouse. If the average price of a weekly lighthouse rent is $700 €$, the average income of the lighthouse is $13,300.00 €$, which is $159,600.00 €$ on the annual level for all the lighthouses (Lighthouse pricelist, 2017).

On the basis of an analysis of income and expenditures, the profitability of this business can be estimated (see Figure 4). 


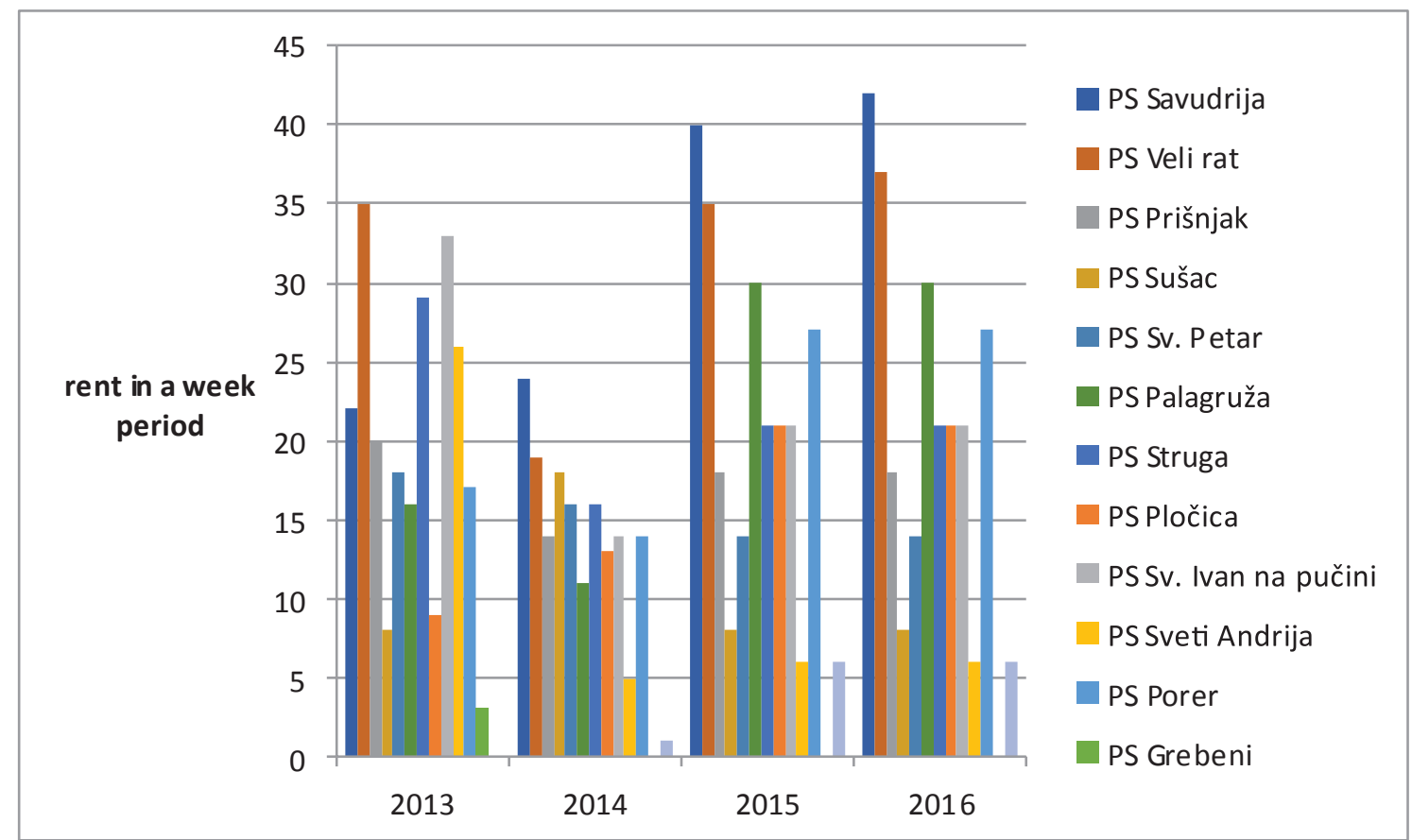

Figure 3.

Weekly rental of maritime lighthouses by years.

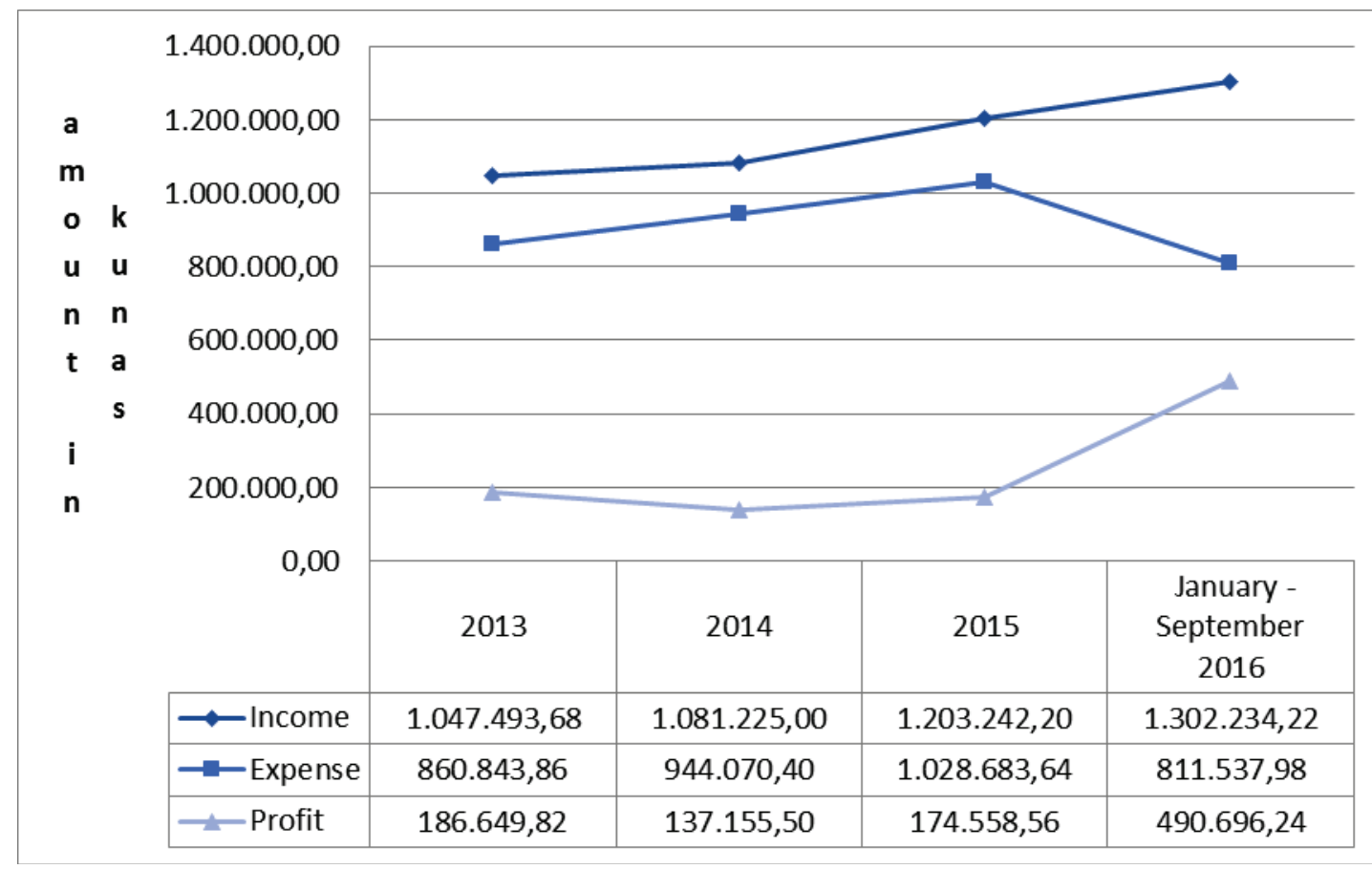

Figure 4

Profitability from tourist rent of maritime lighthouses. 
The results of the collected and processed data show that additional investment in lighthouse tourism is more than profitable. Plovput did not operate negatively in the tourism department in the past 4 years, but had a constant profit, which in 2016 resulted in 490,696.24 kn $(65,426.17 €)$.

\section{CONCLUSION}

The maritime lighthouses in the Republic of Croatia as well as worldwide have the main purpose of signalling at sea, all in order to protect human lives and property at sea. It should be noted that in the Republic of Croatia there have been no marine accidents resulting in casualties, caused by the failure of maritime signalling (lighthouse).

As automation and technology are dominant nowadays, there is a question to be made about the adequate use of lighthouses which have enormous potential in tourist terms. Due to the lack of material resources, and perhaps the poor coordination of the Ministry (maritime affairs - tourism) and Plovput, the exploitation of this type of tourist facilities is not at an enviable level. On lighthouses that are rented by Plovput, new employment is required - not a lighthouse keeper, but a maid, chef, waiter, hair-dresser, so that the tourist offer itself would be of higher quality and more competitive. Tourist service is an additional service provided by Plovput and as such has no priority investment.

The advantages that have been shown of renting a lighthouse with regard to those which are not rented are enormous, and it is necessary to put all the lighthouses in the function of tourism as soon as possible. The lighthouses that are not in the function of tourism and do not have a lighthouse keeper are decaying, primarily because of the dampness and there is also the technical sustainability for which the lighthouse keeper cares. Safety in navigation is not questionable in these cases as the light is automated, and in case of the main light failure, the auxiliary one will be activated immediately.

The intervention by Plovput happens within 24 hours, of course with weather allowance. According to the latest data from Plovput, such cases are only in the range of 1-5 during the year and all are removed within 24 hours, which indicates 100 $\%$ efficiency. Thus, maritime signalling is at a high level in the Republic of Croatia, which cannot be said for the tourist part. Lighthouses are a new and recognisable tourist attraction that brings profit, and the data on the availability of accommodation capacities indicates their growth in the future.

\section{REFERENCES}

Lighthouse pricelist - Lighthouses Croatia, available at: http://www.lighthousescroatia.com/hr/cjenik, [accessed 27 June 2017].

Izvod iz registra kulturnih dobara Republike Hrvatske, (01/2011), Narodne novine 2011(76), Available at: http://narodne-novine.nn.hr/clanci/ sluzbeni/2011_08_92_1957.html, [accessed 12 May 2017].

Jeremić, Lj., (2014), Sustav daljinskog nadzora rada objekata pomorske signalizacije, Sveučilište u Rijeci: Pomorski fakultet, available at: http://www.pfri.uniri.hr/ knjiznica/NG-dipl.LMPP/284-2014.pdf, [accessed 22 May 2017].

Kasum, J., Cvjetković, S. J. and Stanivuk, T., (2013), Dynamic Model for Calculating the VHF Radio Horizon at Sea, Brodogradnja 64(4), pp. 482 - 487.

Pearson, L. F., (1995), Lighthouses, Buckinghamsire: Shire Publications LTD.

Perišić, M., Župarić, J. and Andrijanić, G., (2010), Sanacija svjetioničarskih zgrada i njihovo valoriziranje kroz komercijalne djelatnosti, Ekonomski vjesnik 23(1), pp. 170 -179 .

PLOVPUT LLC, available at: http://www.plovput.hr/en/aids-to-navigation/ lighthouses/lighthouse, [accessed 12 June 2017].

Pomorski rječnik, Pritchard, available at: https://www.scribd.com/ document/348617952/Pomorski-Rjecnik-Pritchard, [accessed 25 May 2017].

Popović, R., Kulović, M. and Stanivuk, T., (2014), Meteorological Safety of Entering Eastern Adriatic Ports, Transactions on Maritime Science - ToMS 3(1), pp. 53 - 60., available at:

https://doi.org/10.7225/toms.v03.n01.006

Šerić, N., (2001), Kamena svjetla. Split: Marjan tisak.

Šerić, N., Realizacija II faze složenog investicijskog projekta Kamena Svjetla - sanacija i revitalizacija svjetioničarskih zgrada bez ljudske posade, available at: https://bib. irb.hr/datoteka/408451.II_FAZA_PROJEKTA_KAMENA_SVJETLA.doc, [accessed 20 June 2017].

Zakon o Plovputu, (1997), Narodne novine, 1997(73), članak 2. 